\title{
Detection of West Nile virus in wild birds in Tana River and Garissa Counties, Kenya
}

\author{
Doris Nyamwaya ${ }^{1,3^{*}}$ D, Virginia Wang'ondu ${ }^{3}$, Joshua Amimo², George Michuki ${ }^{1}$, Moses Ogugo ${ }^{1}$, Enoch Ontiri ${ }^{1}$, \\ Rosemary Sang ${ }^{4}$, Johanna Lindahl' ${ }^{1}$, Delia Grace ${ }^{1}$ and Bernard Bett ${ }^{1 *}$
}

\begin{abstract}
Background: West Nile fever virus is a zoonotic arboviral infection maintained in a sylvatic cycle involving mosquito vectors and birds. It is one the arboviruses whose geographical range is expanding because of climate and land use changes that enhance the densities of mosquitoes and promote mosquito-bird-human interactions. We carried out a survey to determine the reservoirs of WNV among wild birds in Tana River and Garissa counties, Kenya.

Methods: Blood samples were obtained from 361 randomly trapped wild birds. Using real-time polymerase chain reaction $(P C R)$, all samples were screened for WNV using gene specific primer sets amplifying a portion of the $E$ region of the genome encoding the envelope protein.

Results: Sixty five (65) out of 361 birds screened tested positive for WNV on real-time PCR assay. Sequencing of the selected positive samples reveals that the isolated WNV were most closely related to strains isolated from China (2011). A regression analysis indicated that sampling location influenced the occurrence of WNV while species, age, weight and sex of the birds did not have any effect.

Conclusions: This study provides baseline information on the existing circulation of WNV in this region among wild bird reservoirs that could spill over to the human population and points to the need for implementation of surveillance programs to map the distribution of the virus among reservoirs. Awareness creation about West Nile fever in this region is important to improve its detection and management.
\end{abstract}

Keywords: Arbovirus, Flavivirus, Emerging infectious disease, West Nile fever, Zoonosis

\section{Background}

West Nile virus (WNV) is a small single-stranded RNA virus classified under the genus flavivirus and grouped in the Japanese encephalitis virus sero-complex $[1,2]$. It was first isolated from a febrile patient in Uganda [3] and is now one of the re-emerging zoonotic mosquitoborne pathogens whose occurrence has spread in a wide geographic range with major epidemics reported globally [4-6]. Similar to the other neurotropic flaviviruses, WNV is mainly transmitted by Culex mosquitoes with wild birds as the reservoirs and amplifying hosts $[7,8]$. A higher competence among passerines has been demonstrated by their high susceptibility and ability to maintain high viremia for a prolonged duration [9]. While

\footnotetext{
*Correspondence: kemuntodoris1@gmail.com; b.bett@cgiar.org ${ }^{1}$ International Livestock Research Institute, P. O. Box 30709, 00100 Nairobi, Kenya

Full list of author information is available at the end of the article
}

birds seems to be the most important reservoirs for WNV, antibodies againts the virus have also been detected in many mammals, some reptiles and amphibians [10], but the role of these species is not always understood. Humans and equines are incidental hosts as they produce insignificant viremia and do not contribute to WNV transmission. In most instances, the infection in human is mild and asymptomatic with less than $1 \%$ of patients developing meningoencephalitis, that often result in death [11].

Epidemics due to WNV have not been reported in Kenya. Studies have however demonstrated its presence in mosquitoes collected from the North Eastern Province [12, 13] and Turkwel gorge in the Rift Valley province where vertical transmission of the virus in Culex univittatus was observed [14]. Culex

(c) The Author(s). 2016 Open Access This article is distributed under the terms of the Creative Commons Attribution 4.0 International License (http://creativecommons.org/licenses/by/4.0/), which permits unrestricted use, distribution, and reproduction in any medium, provided you give appropriate credit to the original author(s) and the source, provide a link to the Creative Commons license, and indicate if changes were made. The Creative Commons Public Domain Dedication waiver (http://creativecommons.org/publicdomain/zero/1.0/) applies to the data made available in this article, unless otherwise stated. 
quinquefasciatus, Cx. univittatus, and Cx. vansomereni have been implicated as potential WNV vectors [15]. A sero-epidemiological survey that involved local communities in Tana River and Ijara Kenya, just before this study was initiated, indicated that people from irrigated areas were 1.27 times more likely to get exposed to WNV than those from pastoral areas [16]. A similar survey conducted in the local health centers among patients that sought treatment for febrile illnesses showed presence of WNV antibodies [16]. These studies indicated the presence and circulation of WNV in the region, and the potential importance of irrigation as a risk factor. This present study therefore sought to identify potential reservoirs (wild birds) of the virus to better understand its transmission cycle. This would provide insights for the development of surveillance, control and prevention strategies. The study was also designed to determine the lineage(s) of the WNV strains found in the area given that previous studies showed that both lineages 1 and 2 were present in the region.

\section{Methods}

\section{Description of the study area}

The study area traversed two neighboring counties Tana River and Garissa - in the eastern part of Kenya
(Fig. 1). Tana River County is located between $38.45^{\circ}-$ $40.66^{\circ} \mathrm{E}$ and $3.04^{\circ}-0.00^{\circ} \mathrm{S}$ while Garissa County is located between $38.67^{\circ}-41.52^{\circ} \mathrm{E}$ and $2.04^{\circ}-1.00^{\circ} \mathrm{S}$. The area falls in an arid to semi-arid area with annual rainfall ranging between 400 and $750 \mathrm{~mm}$ and mean annual temperatures varying from $30{ }^{\circ} \mathrm{C}$ to $33{ }^{\circ} \mathrm{C}$. It has a unique habitat diversity ranging from forests, woodlands, grasslands, riverine, mangroves, sand dunes and bushlands. The main economic activities in the area are farming and pastoralism. There are on-going large and small scale irrigation projects specifically in the sites falling in the Tana River County that produce maize, green grams and bananas among other food crops. Due to water pools in the irrigation schemes coupled with the hot and humid climatic conditions, there is a high mosquito density.

\section{Sampling}

Birds were trapped in the dry and hot month of October 2014 and during the rainy season in December 2014. Cross sectional sampling was done for 14 days each occasion. Sites for bird trapping were selected randomly in Hola, Bura and Ijara. Mist nets $(12 \mathrm{~m}$ length by $2 \mathrm{~m}$ height, $38 \mathrm{~mm}$ mesh and 6 panels) suspended $30 \mathrm{~cm}$ above the ground using bamboo poles $3 \mathrm{~m}$ long were used [17]. All Trapped birds were picked as soon as

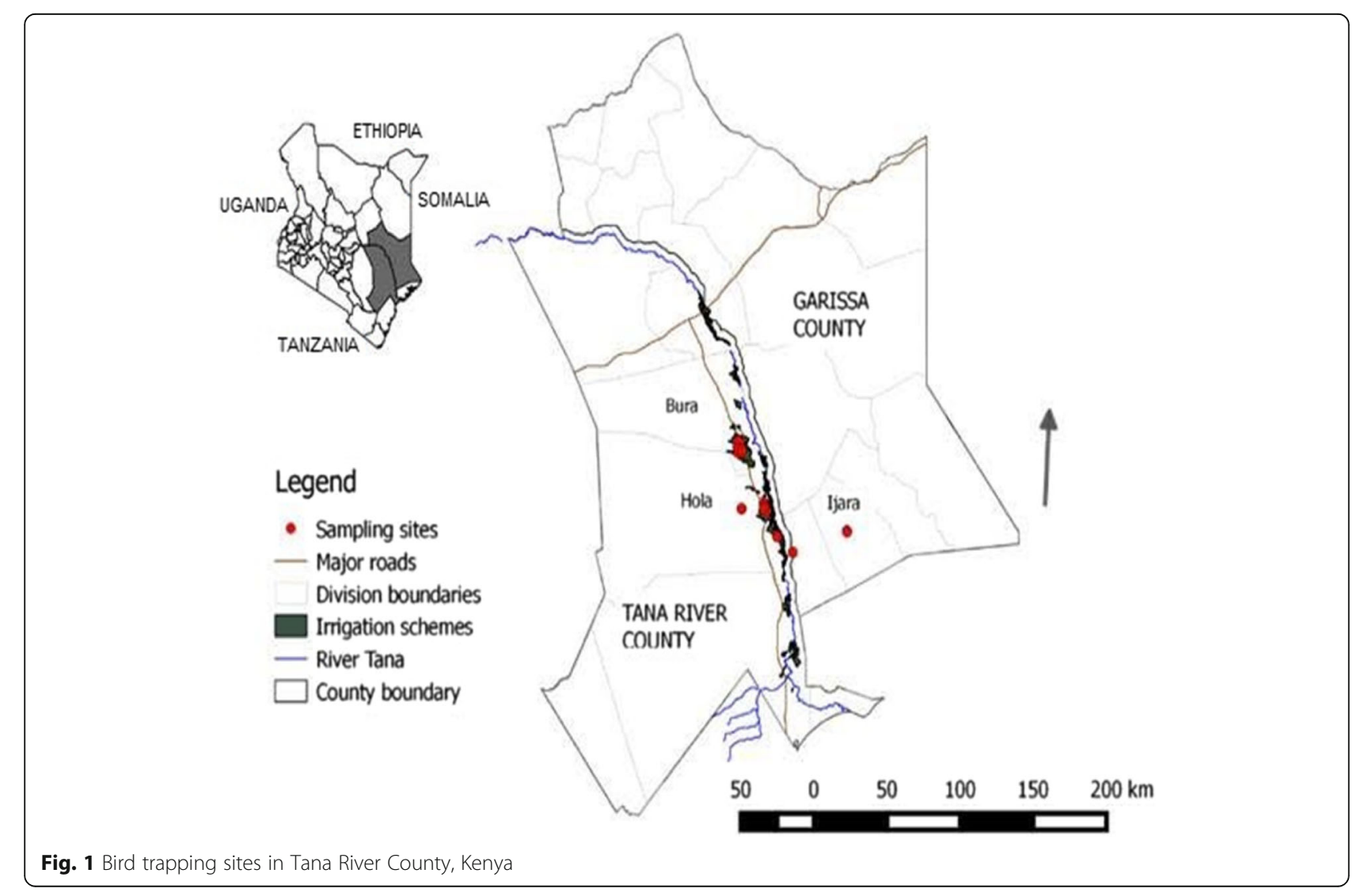


netting was observed to minimize traumatic stress on the trapped bird and the corresponding time was indicated. Extracted birds were placed in clean cotton bird bags in the shade and sampled according to standard ornithological bird handling and processing procedure [18]. Data recorded included species identification, estimated age, sex, and weight. The tail, tarsus, wing and head lengths were also recorded. Each bird was banded using a labeled ring from the National Museums of Kenya (NMK) for follow up purpose and to avoid resampling. Under aseptic conditions, blood was obtained from the brachial vein by a qualified and licensed ornithologist from NMK. In the month of October, blood samples were dispensed into sterile barcoded vials that were racked and stored in solid carbon dioxide $\left(-78.5^{\circ} \mathrm{C}\right)$. Due to the technical, logistical and cost challenges arising from the use of dry ice, a decision was made to switch to Whatman ${ }^{\circ}$ FTA $^{\bullet}$ card technology [19] for blood sample collection in December.

\section{Ribonucleic Acid (RNA) Extraction}

Total RNA was extracted from blood using MagNA ${ }^{\circ}$ Pure LC RNA Isolation Kit (Roche Diagnostics, Manneheim, Germany) according to the manufacturer's instructions. Briefly, blood samples in vials were first thawed in ice and $200 \mu \mathrm{l}$ transferred into a sample cartridge after a brief vortex. The FTA ${ }^{\circ}$ card blood spots were punched out in small pieces, transferred into $1.5 \mathrm{ml}$ sterile eppendorf tubes unto which $70 \mu \mathrm{l}$ phosphate buffered saline (PBS) was added. After incubation for $5 \mathrm{~min}$ at room temperature, $200 \mu \mathrm{l}$ of TriZol reagent was added and the contents vortexed for $3 \mathrm{~s}$ then incubated at room temperature for $3 \mathrm{~h}$ before transferring to a sample cartridge for RNA extraction and elution. The quantity and purity of the eluted RNA after the automated extraction was determined using a NanoDrop ND-1000 spectrophotometer (Thermo Scientific, Walton, Massachusetts, USA) before storage at $-80{ }^{\circ} \mathrm{C}$ until use.

\section{Reverse transcription}

Complementary DNA was synthesized from the extracted RNA with SuperScript ${ }^{\text {tm }}$ II (SS II) first strand synthesis system for RT-PCR (Invitrogen) following manufacturer's instructions. For each reaction, $4 \mu \mathrm{l}$ of sample total RNA was combined with $2 \mu \mathrm{l}$ of random hexamers and heated at $65{ }^{\circ} \mathrm{C}$ for $5 \mathrm{~min}$ then placed on ice immediately for $1 \mathrm{~min}$ to anneal the primers to the 3 ' terminal sequences of the RNA. SuperScript ${ }^{\mathrm{Tn}}$ II reverse transcription mix was prepared according to the manufacturer's instructions. Each reaction contained $4 \mu \mathrm{l} 5 \mathrm{X}$ First strand buffer $(250 \mathrm{mM}$ Tris- $\mathrm{HCl}, \mathrm{pH} 8.3$ at room temperature, $375 \mathrm{Mm} \mathrm{KCL}, 15 \mathrm{mM} \mathrm{MgCL} 2), 2 \mu \mathrm{DTT}$ $(0.1 \mathrm{M}), 2 \mu \mathrm{l}$ Bovine Serum Albumin $(10 \mathrm{mg} / \mathrm{ml}), 1 \mu \mathrm{l}$
dNTPs $(10 \mathrm{Mm}), 0.2 \mu \mathrm{l} \mathrm{RNase}^{\mathrm{Tw}} \mathrm{OUT}(40 \mathrm{U} / \mu \mathrm{L})$ and $0.5 \mu \mathrm{l}$ of SS II and then incubated for $2 \mathrm{~min}$ at $25{ }^{\circ} \mathrm{C}$. To each of the reaction wells containing heated RNA and primer mix, $9.7 \mu \mathrm{l}$ of the prepared mix was added, gently pipetted up-down to mix contents and centrifuged at $12,000 \mathrm{rpm}$ for 30s. The mix was annealed at $25^{\circ} \mathrm{C}$ for $10 \mathrm{~min}$, extended at $42{ }^{\circ} \mathrm{C}$ for $15 \mathrm{~min}$ and then the reverse transcription enzyme was inactivated by incubating for $15 \mathrm{~min}$ at $70{ }^{\circ} \mathrm{C}$ then chilled at $4{ }^{\circ} \mathrm{C}$.

\section{WNV screening}

West Nile virus specific primers amplifying part of the highly conserved envelope-protein coding region of the WNV NY99 strain (reverse primer '1845' of sequence 5' TTCCATCTTCACTCTACACT - 3 ' and forward primer '1401' of sequence 5' ACCAACTACTGTGGAGTC -3') [20] purchased from Bioneer ${ }^{\circ}$ and diluted to a final working concentration of $20 \mathrm{pM}$ in sterile water were used. Screening was done in a real-time polymerase chain reaction (PCR) against a standard curve generated by a synthetic WNV positive control $\left(\mathrm{GenScript}^{\circ}\right)$. Into each well of a sterile labelled MicroAmp ${ }^{\text {tw }}$ fast 96 well reaction plate, $12.5 \mu \mathrm{L} \mathrm{SyBr}{ }^{\bullet}$ Green master mix $0.5 \mu \mathrm{l}$ of each primer (forward primer '1401' and reverse primer ' $1845^{\prime}$ ), $10 \mu \mathrm{l}$ of sterile PCR water (Bioline ${ }^{\circ}$ ) and $1.5 \mu \mathrm{l}$ of synthesized cDNA were added. The plate was sealed using MicroAmp ${ }^{\text {Tw }}$ clear adhesive films (ABI) and loaded into 7900HT fast Real-time PCR system (Applied Biosystems). Thermal cycling conditions consisted of initial denaturation at $95{ }^{\circ} \mathrm{C}(10 \mathrm{~min}), 35$ cycles of denaturation at $95{ }^{\circ} \mathrm{C}(30 \mathrm{~s})$, annealing at $49{ }^{\circ} \mathrm{C}(45 \mathrm{~s})$ and extension at $72{ }^{\circ} \mathrm{C}(45 \mathrm{~s})$, a dissociation cycle $95{ }^{\circ} \mathrm{C}(15 \mathrm{~s}), 60{ }^{\circ} \mathrm{C}(15 \mathrm{~s})$, $95^{\circ} \mathrm{C}(15 \mathrm{~s})$ and a hold at $10{ }^{\circ} \mathrm{C}$.

Sample amplification with a cycle threshold score of less than 40 was considered positive [21]. These products were analyzed by agarose gel $(1.5 \% \mathrm{w} / \mathrm{v})$ electrophoresis and visualized under UV illumination after GelRed $^{\text {mx }}$ (Biotium) staining. Samples with specific targeted $445 \mathrm{bp}$ fragments were purified using a mini-elute purification kit (Qiagen) according to the manufacturer' instructions and if the concentration was good quality with a concentration above $20 \mathrm{ng} / \mu \mathrm{l}$ submitted for Sanger sequencing using Big Dye Terminator Cycle chemistry and 3730 DNA Analyzer (Applied Biosystems, Foster, CA). The nucleotide sequences obtained from the selected strains were compared with the same segment of similar sequences of known strains available in GenBank using nBLAST (http://www.ncbi.nlm.nih.gov/ BLAST/).

\section{Data analysis}

In order to establish the relationship between the occurrences of WNV, the site of sampling and bird characteristics (age, sex and species), a regression analysis in a 
generalized linear model with a logit link implemented in R software was used. The Hosmer Lemeshow test was then used to test for the goodness of fit for this model. The confidence limit for the statistical tests was set at 95\% $(P<0.05)$. The DNA sequences were aligned using a multiple sequence alignment program, Clustal Omega (http://www.ebi.ac.uk/Tools/msa/clustalo/) and the sequence identity calculated using the same program. Sequences with short read lengths below 200 bases were excluded from further analysis. The dendrogram was constructed using the neighbor-joining method supported with a bootstrap test of 1000 replicates in MEGA 6 software [22].

\section{Results}

A total of 449 birds grouped into 61 species were trapped, of which 361 birds were sampled as the rest either escaped $(0.7 \%)$ or were too weak to be bled (8.9\%). The most frequently sampled species was the red-billed Quelea $(n=81)$, lesser masked weaver birds $(n=57)$ and ring-necked doves $(n=34)$ (Additional file 1). All age groups and sex of birds were represented in the sample with most of the captured birds being adult males $(n=$ 129). A total of 65 samples (18\%) recorded a cycle threshold score of real time RT-PCR below 40 with a mean of $8.53^{-11}\left(\mathrm{sd}=6.12^{-11}\right)$ for detected WNV copies/ $\mathrm{ml}$ and were considered positive (Fig. 2). In the month of December, only birds trapped from Bura tested positive, while there were infected birds from all the sampling sites in October (Table 1).
A regression analysis using a generalized linear model which included bird's age, sex, region of capture and species as independent factors showed that only the region of capture had a significant effect $(p=0.01)$ on WNV occurrence with birds from Hola and Ijara being less likely to harbor the virus compared to birds from Bura where there are more extensive irrigation schemes.

After PCR product purification, 35 samples were good quality and were sequenced. Except for 3 sequences with read lengths between 200 and 450 bases, the rest had short read lengths and were excluded from further analysis. A similarity search using nBLAST tool in the NCBI database revealed a high similarity between Tana River WNV strains and WNV strains detected in China (2011) (GeneBank accession numbers: XJ11141, XJ11129 and $X$ J11148). A sequence identity comparison table generated by incorporating retrieved sequences of WNV isolates from the Genebank (NCBI) and sequences from this study (accession numbers; KX189175, KX189174 and KX189176) showed differential similarity of Tana River strains to other WNV isolated strains. Identity to published strains grouped under Lineage I were all above 95\% except for Kenya tick strain, while sequence similarity between our samples and lineage II -IV was below 70\% (Table 2).

Phylogenetic analysis by maximum likelihood method conducted in MEGA6 [22] incorporating other published WNV strains available in GenBank with strains in this study, further confirmed the close evolutionary relationship to WNV strains described as Lineage 1 [23] (Figs. 3 and 4).

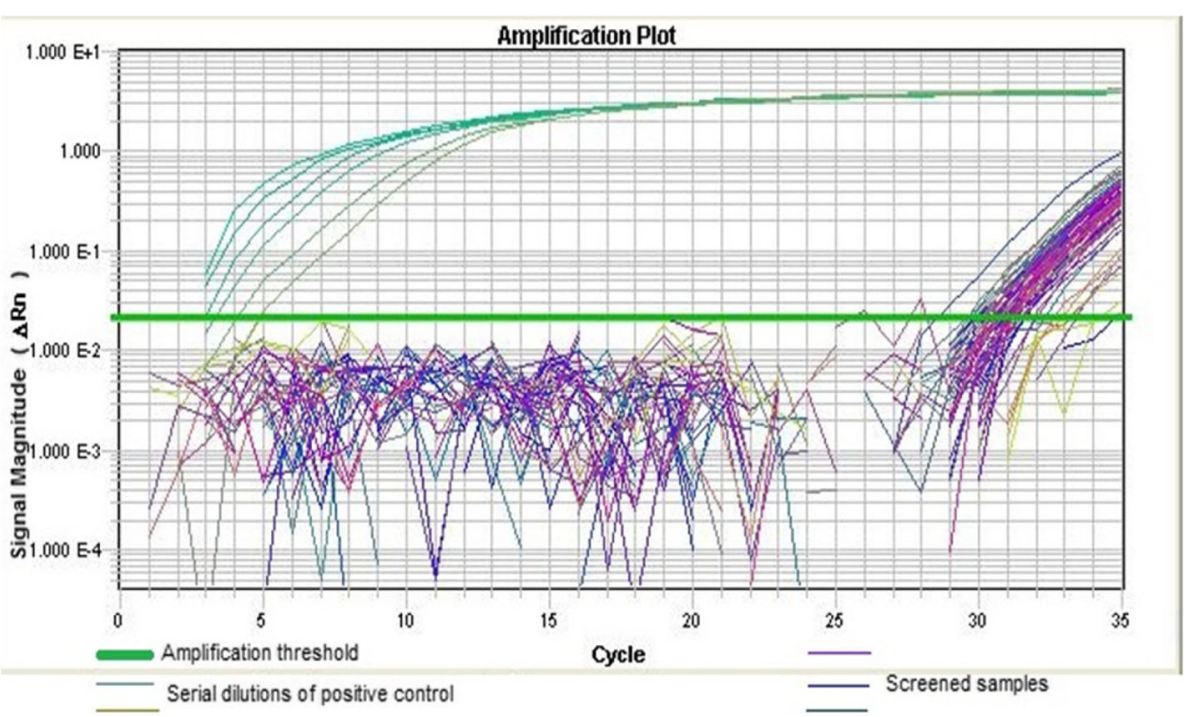

Fig. 2 Fluorescence signal magnitude plot against PCR cycles generated from the real- time PCR: Serial dilutions of the positive control generated detectable amplification signals before the $5^{\text {th }}$ cycle. The screened samples that were positively amplified generated detectable amplification signals after the $25^{\text {th }}$ cycle. Positive samples had a CT value above 25 
Table 1 Frequency distribution of bird species positive for WNV

\begin{tabular}{|c|c|c|c|c|c|c|}
\hline \multirow[t]{3}{*}{ Species } & \multirow[t]{3}{*}{ Frequency } & \multicolumn{5}{|c|}{ WNV Positive Samples } \\
\hline & & \multicolumn{2}{|l|}{ BURA } & \multirow{2}{*}{$\begin{array}{l}\text { HOLA } \\
\text { October }\end{array}$} & \multirow{2}{*}{$\begin{array}{l}\text { IJARA } \\
\text { October }\end{array}$} & \multirow[t]{2}{*}{ Total } \\
\hline & & October & December & & & \\
\hline African golden weaver & 8 & & 2 & & & 2 \\
\hline African mourning dove & 3 & & 1 & & 1 & 2 \\
\hline Barn swallow & 5 & & 2 & & & 2 \\
\hline Emerald spotted wood dove & 9 & & & & 2 & 2 \\
\hline Golden breasted starling & 4 & & & & 1 & 2 \\
\hline Golden pipit & 8 & & 2 & & & 2 \\
\hline Grey headed king fisher & 3 & 1 & & & & 2 \\
\hline House sparrow & 22 & 4 & & & & 2 \\
\hline Laughing dove & 24 & & 3 & 1 & & 4 \\
\hline Lesser masked weaver & 43 & & 4 & 10 & & 14 \\
\hline Namaqua dove & 24 & & 4 & 1 & & 5 \\
\hline Nightjar & 1 & & & & 1 & 1 \\
\hline Nubian wood pecker & 6 & & & & 1 & 1 \\
\hline Red billed quelea & 68 & 8 & 1 & 3 & & 12 \\
\hline Ring necked dove & 22 & & 1 & & 2 & 3 \\
\hline Ruppel's long tailed starling & 10 & & & & 2 & 2 \\
\hline Violet backed sunbird & 1 & & 1 & & & 1 \\
\hline White browed sparrow weaver & 2 & 1 & & & & 1 \\
\hline White headed buffalo weaver & 15 & 1 & & & 3 & 4 \\
\hline White throated bee eater & 2 & & 1 & & & 1 \\
\hline Total & & 15 & 22 & 15 & 13 & 65 \\
\hline
\end{tabular}

\section{Discussion}

This study shows the circulation of WNV among different Kenyan bird species; this information is needed to further understand the risks and epidemiology of the virus in the region. West Nile virus was first detected in East Africa and although the virus has been known for long, there is no established vaccination or curative regimes, it remains a pathogen of public health concern in Africa. After its first isolation in Uganda (1937), a sero-survey (1939-1940) showed a widespread human sero-positivity in Uganda, Kenya, Democratic Republic of Congo and Sudan [24]. In 1950, WNV was isolated for the second time in Egypt during a sero-survey that demonstrated presence of WNV neutralizing antibodies in $70 \%$ of participants [25] indicating a widespread transmission in the local population. West Nile virus is endemic in Kenya and has been isolated from mosquitoes [12,13] and ticks (Rhipicephalus pulchellus) [26] in northeastern Kenya. This study has provided information on the avian amplification hosts that may be significant in maintaining the pathogen in nature.
Tana River County is a rich avifaunal destination supporting both local and migratory birds as revealed by the high diversity of sampled birds in this study. Bird species as a factor did not influence the occurrence of WNV in Tana River, concurring with studies which showed that transmission of WNV in the old world was dependent on presence of a carrier avian host, ornithophilic vectors and interspecies infection of numerous bird amplifying hosts in a given locality [27] independent of the bird species. Despite the 1999 WNV outbreak in New York being characterized by massive deaths of American crows (Corvus brachyrhynchos) [28], passerine bird species have been implicated as the most competent WNV hosts in Africa [29, 30] as they develop high viremia levels with low mortality [9] that allow for transmission to competent mosquito vectors. This is confirmed in this study as more passerine species screened were positive for WNV. Presence of WNV in doves was observed, however, they have been described in previous studies in Egypt and South Africa to be only weakly competent amplifiers of WNV [29, 30]. 
Table 2 Percentage nucleotide identity between WNV isolates available in Genebank and Tana River WNV strains

\begin{tabular}{|c|c|c|c|c|}
\hline WNV STRAINS & Lineage & KX189174_R.b.quelea_2D_2016_Bura_Kenya & KX189175_Dove_4A_2016_Bura_Kenya & KX189176_Dove_4B_2016_Bura_Kenya \\
\hline DQ118127_goose-Hungary/03 & I & 96.9 & 95.2 & 96.9 \\
\hline KJ786934_NY2001-6263_Homosapiens & I & 97.6 & 95.9 & 96.9 \\
\hline KT163243_68856-ICDC-4_2015_India & । & 95.9 & 94.1 & 95.2 \\
\hline JX442279_XJ11129_C.pipiens_2011_China & । & 100.0 & 97.9 & 99.3 \\
\hline JX442281_XJ11141_C.pipiens_2011_China & । & 100.0 & 97.9 & 99.3 \\
\hline DQ374650_Ast02-3-717_P.carbo_2006_Russia & । & 99.7 & 97.9 & 99.0 \\
\hline DQ411031_Ast01-187_C.corone_2006_Russia & । & 99.7 & 97.9 & 99.0 \\
\hline DQ411030_Ast01-182_H.Marginatum_2006_Russia & । & 99.7 & 97.9 & 99.0 \\
\hline KJ501417_WNV-1/US/BID-V6684/2006 & । & 98.3 & 96.2 & 97.6 \\
\hline EF631149_CpWw21_CpWw21_Cx.pipiens_2006_USA & । & 98.3 & 96.2 & 97.6 \\
\hline HM538818_4893_2007_USA_linaege 2 & । & 98.3 & 96.2 & 97.6 \\
\hline DQ786573_France407/04_C.magpie_2004_France & । & 96.2 & 94.5 & 95.5 \\
\hline AY712947_Bird1461_2004_Tx_USA & । & 97.9 & 96.2 & 97.2 \\
\hline AY052409_Goose_ISR98-GooKha_1998_Israel & । & 97.2 & 95.5 & 96.6 \\
\hline KC243146_tick_ATH002316_2006_Kenya & । & 92.8 & 91.0 & 92.1 \\
\hline KX189174_R.b.quelea_2D_2016_Bura_Kenya & । & 100.0 & 97.9 & 99.3 \\
\hline KX189175_Dove_4A_2016_Bura_Kenya & । & 97.9 & 100.0 & 97.2 \\
\hline KX189176_Dove_4B_2016_Bura_Kenya & । & 99.3 & 97.2 & 100.0 \\
\hline DQ318019_WNV_ArD76104_2006_Senegal & $\|$ & 75.5 & 73.8 & 75.5 \\
\hline HM147822_WNV_1958_SAfrica_lineage2 & $\|$ & 75.2 & 73.8 & 75.2 \\
\hline EF429199_human_SA381/00_2000_S.Africa & $\|$ & 76.9 & 75.2 & 76.9 \\
\hline GQ903680_Q3574-5_1968_Cyprus & $\|$ & 75.3 & 73.9 & 75.3 \\
\hline HM147824_1958_DRCongo & $\|$ & 76.6 & 74.8 & 76.6 \\
\hline AY688948_Sarafend_2005_Israel & $\|$ & 76.2 & 74.8 & 76.2 \\
\hline AY765264_Rabensburg_C.pipiens_Czech_lineage 3 & III & 77.2 & 75.2 & 77.2 \\
\hline $\begin{array}{l}\text { AY277251_LEIV-Krnd88- } \\
\text { 190_D.marginatus_1998_Russia_Lineage } 4\end{array}$ & IV & 71.7 & 70.0 & 71.0 \\
\hline JN638336_Denguevirus1_KD86-035_1986_outgroup & & 53.0 & 51.6 & 52.3 \\
\hline
\end{tabular}

In bold are sequences obtained from this particular study. Other sequences used in generating the identity matrix were obtained from the genebank 


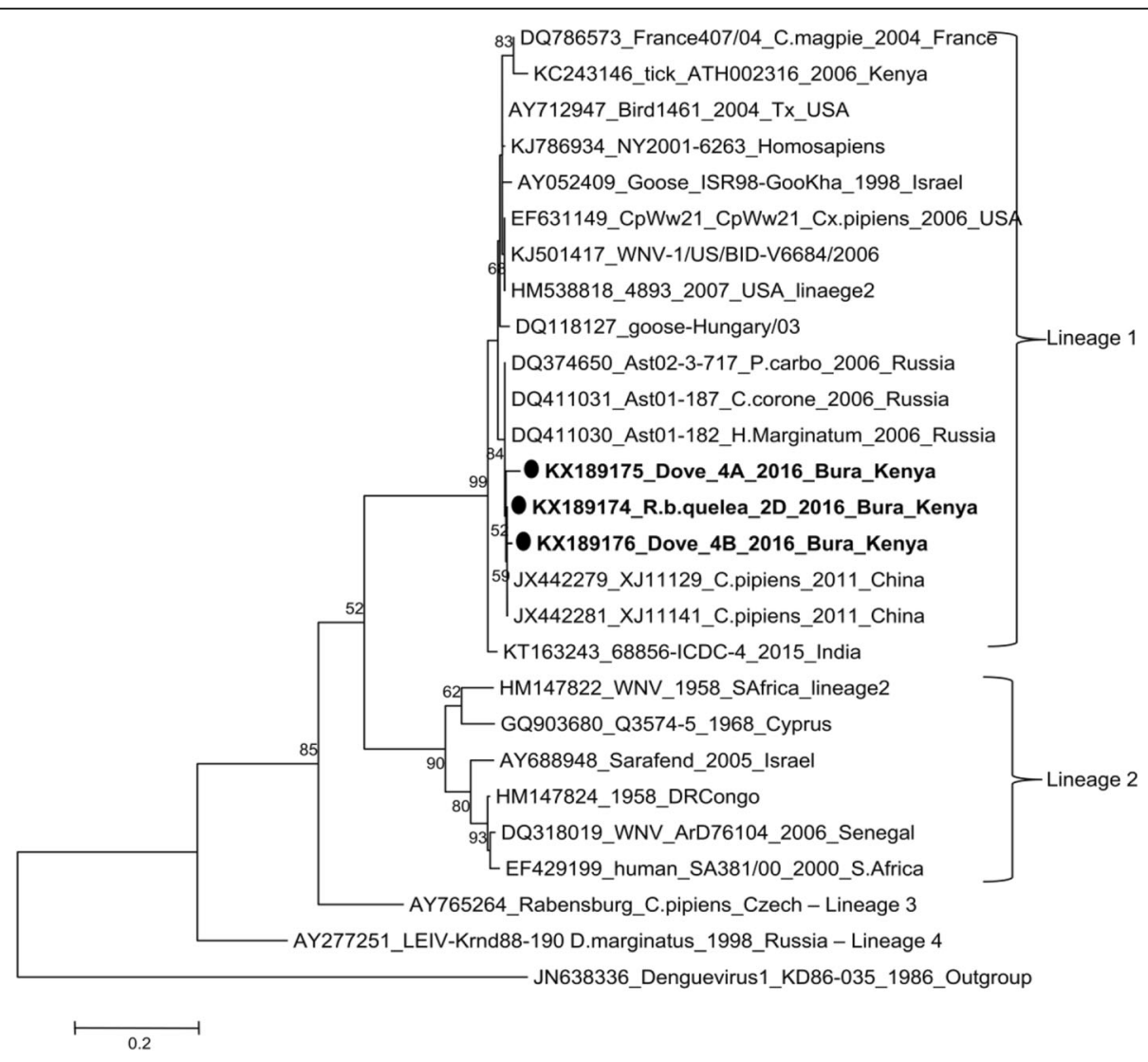

Fig. 3 Molecular phylogenetic analysis by Maximum Likelihood method between Kenyan WNV bird strains (bold) and known WNV strains in the GenBank. The evolutionary history was inferred by using the Maximum Likelihood method based on the Tajima-Nei model [35]. The tree with the highest log likelihood $(-1866.0300)$ is shown. The percentage of trees in which the associated taxa clustered together is shown next to the branches. Initial tree(s) for the heuristic search were obtained automatically by applying Neighbor-Join and BioNJ algorithms to a matrix of pairwise distances estimated using the Maximum Composite Likelihood (MCL) approach, and then selecting the topology with superior log likelihood value. Evolutionary analyses were conducted in MEGA6 [22]

Despite improving food security in the semi-arid county, irrigation activity has led to increased mosquito densities and occurrence of zoonotic pathogens including WNV [16]. In this study, there were more WNV positive bird blood samples from Bura, a region that has a larger irrigated area in comparison to other sampled regions and is likely to attract more birds due to availability of a higher food base and high mosquito density. This was the same trend observed with sero-positivity to WNV during surveillance studies of human blood samples in this locality with patients from irrigated sites exhibiting high prevalence rates [16].

The geographic and genetic diversity of WNV has been previously described with five distinct lineages proposed from phylogenetic analyses of various isolates [23, 31, 32]. Most human outbreaks have been associated with lineages 1,2 and 5 [23,33]. Lineage 1 isolates have a wide geographic distribution globally and have evolved into clades $1 \mathrm{a}$ and $1 \mathrm{~b}$ that have been divided further into subclades (Fig. 4). Despite WNV strains from Tana River County exhibiting high similarity to lineage $1 \mathrm{WNV}$ strains (ranging from 80 to $96 \%$ ), they tended to be more similar to each other when compared to those isolated from different geographical localities (Fig. 4). This would be an indication that a particular strain of WNV was introduced to this locality by an infected migratory bird [6] and its existence has been maintained through amplification in local resident bird species and transmission through diverse mosquito species. Phylogenetic analysis of selected sequences revealed that WNV strain from the study region is genetically most closely related to WNV strains XJ11141 and XJ11129 isolated in 2011 from mosquitoes in Xinjiang Uyghur, western China [34]. The E gene from the Xinjiang strains showed a high degree of genetic identity of lineage 1 with other highly pathogenic WNV strains, such as Ast01-182 from Russia [34]. This would be a confirmation to the rapid transmission and distribution of the virus globally. 


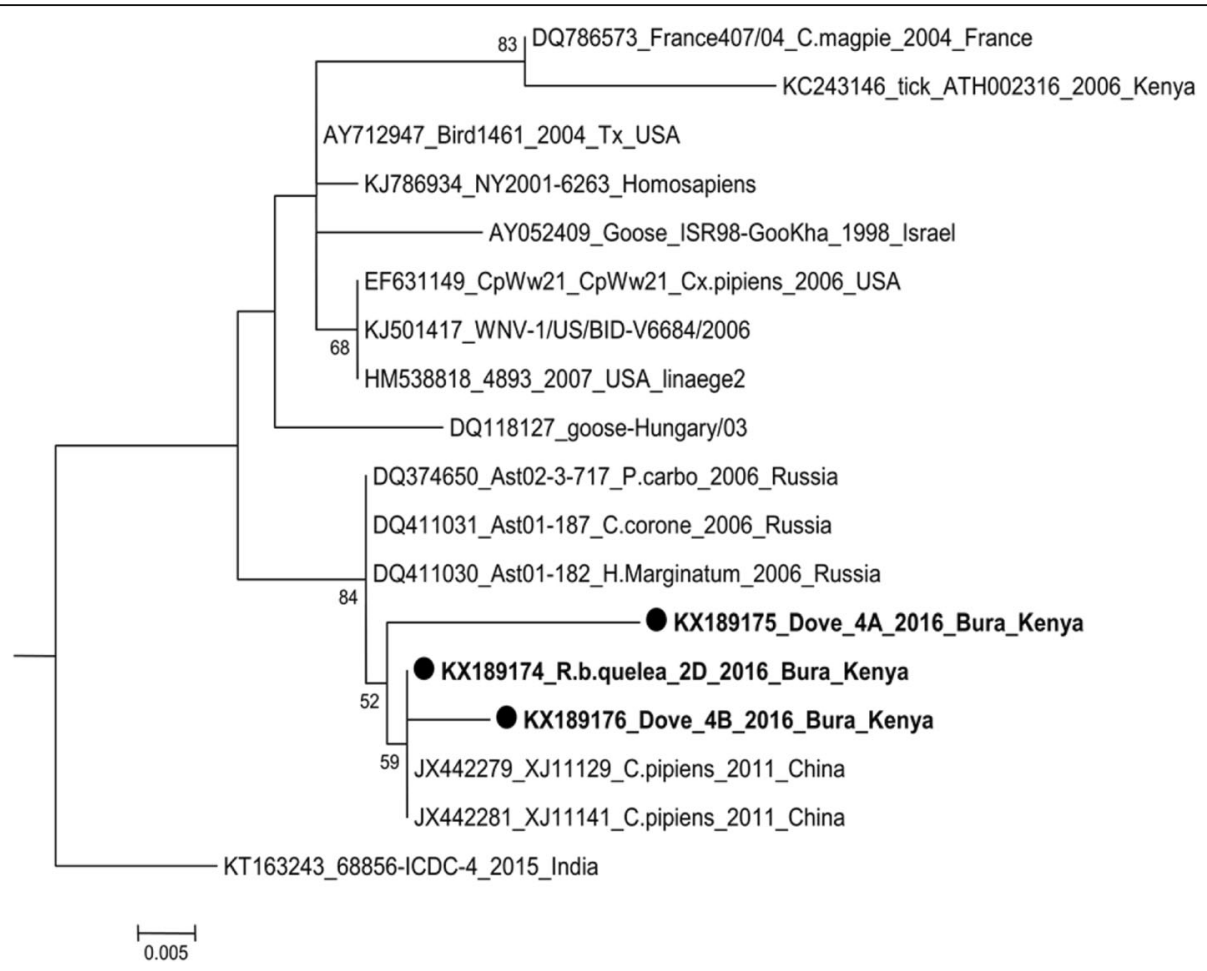

Fig. 4 Phylogenetic tree of WNV lineage 1 strains: The lineage includes different evolutionary clades. Tana River strains (accession numbers: KX189175, KX189174 and KX189176) clustered together indicating that they are closely related

\section{Conclusion}

This study confirms circulation of WNV among wild birds in Tana River, Kenya. Availability of good breeding grounds for mosquito vectors and adequate food base for birds in this county are among factors that would enhance propagation of this pathogen. Since the virus has been reported to rapidly expand its geographical range and epidemic development, there is need to promote awareness in the public health departments and among local residents in order to prevent fatal outbreaks. There is inadequate data on surveillance for active WNV infection in birds and this study therefore provides a baseline for further research to enable adequate comprehension of the ecology of this pathogen in Kenya and assist a potential statement of public health measures to avoid incidents of morbidity and mortality due to sudden disease outbreaks. Although the majority of WNV infections in humans produce mild infections, no studies have been done to demonstrate the virulence of the virus when it infects an immune-compromised individual or when it infect patients with concurrent infections. Tana River provides a roosting (stopover) habitat for migratory birds moving from northern Europe and beyond to the south of the African continent, explaining the flow of virus genes from the north to Tana River. In addition, domestic and wild animals converge here to water which would provide opportunity for further evolutionary changes and emergence of more lineages.
These possibilities suggest an urgent need to conduct more intensive surveillance to determine the intensity of WNV transmission in the area.

\section{Additional file}

Additional file 1: Description: List of Bird Species captured in Tana River County, Kenya. Title: Frequency table of sampled bird species. (DOCX 18 kb)

\section{Abbreviations}

cDNA: Complementary deoxyribonucleic acid; dNTPs: Deoxynucleotides; MEGA: Molecular Evolutionary Genetics Analysis; NCBI: National Center for Biotechnology Information; NMK: National Museums of Kenya; PCR: Reverse transcription polymerase chain reaction; RNA: Ribonucleic acid;

UV: Ultraviolet; WNV: West Nile virus

\section{Acknowledgements}

We thank the National Museums of Kenya for the support they provided in bird trapping and sampling especially the contribution by ornithologists Martin Odino and Lawrence Wagura. We also thank the local community in Bura and Hola for participating in the project.

\section{Funding}

This work was co-funded by CGIAR Research Program on Agriculture for Nutrition and Health (A4NH) led by IFPRI and the Dynamic Drivers of Disease in Africa: Ecosystems, livestock/wildlife, health and wellbeing: REF:NE/J001422/1 project which received funding from the Ecosystem Services for Poverty Alleviation Programme (ESPA). The ESPA program is funded by the Department for International Development (DFID), the Economic and Social Research Council (ESRC) and the Natural Environment Research Council (NERC). 


\section{Availability of data and materials}

The data set supporting the results of this article is depicted in Figures and Tables in the article. Sequences generated from the study have been submitted to the NCBI gene bank and there accession numbers are included in Figs. 3 and 4.

\section{Authors' contributions}

DN contributed in the study design, field sample collection, laboratory analysis, data analysis, and drafting of the first version of the manuscript. BB, WW coordinated the overall process of study design, sample screening, data check and commented on draft versions of the manuscript. GM, MO designed and optimized sample laboratory screening protocols, carried out interpretation of real-time PCR result and commented on the drafted manuscripts. JA performed analysis and interpretation of the sequences data, data check and commented on the drafted manuscript. EO participated in the study design, coordinated the ornithological part of this project, sample collection and commented on the drafted manuscript. RS, JL and DG participated in the study design and commented on the drafted manuscript. All authors of this manuscript have seen and approved the content.

\section{Competing interests}

The authors declare that they have no competing interests.

\section{Consent for publication}

Not applicable.

\section{Ethics approval and consent to participate}

This study was part of a larger study that examined the effects of land use change on the transmission of mosquito-borne infections in livestock and people. The ethical approval for the project was provided by The African Medical Research Foundation, approval number AMREF-ESRC-P65/2013. Bird sampling was done in collaboration with the Ornithology Department, National Museums of Kenya, a state corporation which facilitates ornithological research for international and local institutions in Kenya and Africa. The institution has permits for bird sampling; they used this opportunity to ring captured birds (released after sampling) for future ecological studies. At the local level, consent to sample birds was obtained from community leaders before these birds were trapped and sampled.

\section{Author details}

'International Livestock Research Institute, P. O. Box 30709, 00100 Nairobi, Kenya. ${ }^{2}$ Faculty of Veterinary Medicine, University of Nairobi, P. O. Box 29053, 00625 Nairobi, Kenya. ${ }^{3}$ Department of Microbiology and Marine Botany, School of Biological Sciences, University of Nairobi, P. O. BOX 30197, 00100 Nairobi, Kenya. ${ }^{4}$ U.S. Army Medical Research Unit (USAMRD-K), P.O. Box 606, 00621 Nairobi, Kenya.

\section{Received: 4 May 2016 Accepted: 11 November 2016}

\section{Published online: 23 November 2016}

\section{References}

1. Kuno G, Chang GJ, Tsuchiya KR, Karabatsos N, Cropp CB. Phylogeny of the genus Flavivirus. J Virol. 1998;72:73-83.

2. Mackenzie JS, Barrett ADT, Deubel V. The Japanese encephalitis serological group of flaviviruses: a brief introduction to the group. Curr Top Microbiol Immunol. 2002;267:1-10.

3. Smithburn KC, Hughes TP, Burke a W, Paul JH, African A. A neurotropic virus isolated from the blood of a native of uganda. Am J Trop Med Hyg. 1940; s1-20:471-92.

4. Anis E, Grotto I, Mendelson E, Bin H, Orshan L, Gandacu D, et al. West Nile fever in Israel: the reemergence of an endemic disease. J Infect Elsevier Ltd. 2014;68:170-5.

5. Danis K, Papa a, Papanikolaou E, Dougas G, Terzaki I, Baka a, et al. Ongoing outbreak of West Nile virus infection in humans, Greece, July to August 2011. Euro Surveill. 2011;16:1-5.

6. England TN, Nash D, Mostashari F, Fine A, Miller J, O'Leary D, et al. The outbreak of West Nile virus infection in the New York City area in 1999. N Engl J Med. 2001;344:1807-14.

7. Gould EA. Evolution of the Japanese encephalitis serocomplex viruses. Curr Top Microbiol Immunol. 2002;267:391-404.
8. Mackenzie JS, Gubler DJ, Petersen LR. Emerging flaviviruses: the spread and resurgence of Japanese encephalitis, West Nile and dengue viruses. Nat Med. 2004;10:598-109.

9. Komar N, Langevin S, Hinten S, Nemeth N, Edwards E, Hettler D, et al. Experimental infection of North American birds with the New York 1999 strain of West Nile virus. Emerg Infect Dis. 2003;9:311-22.

10. Glaser A. West Nile virus and North America: an unfolding story. Rev Sci Tech. 2004;23:557-68.

11. Dauphin G, Zientara S. West Nile virus: recent trends in diagnosis and vaccine development. Vaccine. 2007;25:5563-76.

12. Crabtree M, Sang R, Lutomiah J, Richardson J, Miller B. Arbovirus surveillance of mosquitoes collected at sites of active Rift Valley fever virus transmission: Kenya, 2006-2007. J Med Entomol. 2009;46:961-4.

13. LaBeaud a D, Sutherland LJ, Muiruri S, Muchiri EM, Gray LR, Zimmerman $\mathrm{P}$ a, et al. Arbovirus prevalence in mosquitoes, Kenya. Emerg Infect Dis. 2011;17:233-41.

14. Miller BR, Nasci RS, Godsey MS, Savage HM, Lutwama JJ, Lanciotti RS, et al. First field evidence for natural vertical transmission of West Nile virus in Culex univittatus complex mosquitoes from Rift Valley Province. Kenya Am J Trop Med Hyg. 2000;62:240-6.

15. Lutomiah JL, Koka H, Mutisya J, Yalwala S, Muthoni M, Makio A, et al. Ability of selected Kenyan mosquito (Diptera: Culicidae) species to transmit West Nile virus under laboratory conditions. J Med Entomol. 2011;48:1197-201.

16. Bett B, Mohammed S, Sang R, Bukachi S, Lindahl J, Wanyoike S, Njeru DG I. Land use change and the risk of selected zoonotic diseases: observations from a case study in an arid/semi-arid area in Kenya. Oral Present. given 14th Int. Symp. Vet. Epidemiol. Econ. held Yucata, Mex. 2015.

17. Randall NJ, Blitvich BJ, Blanchong JA. Association between agricultural land use and West Nile Virus antibody prevalence in lowa birds. J Wildl Dis. 2013:49:869-78

18. Komar N, Bessoff K, Diaz A, Amador M, Young G, Seda R, et al. Avian hosts of West Nile Virus in Puerto Rico. Vector-Borne Zoonotic Dis. 2012;12:47-54.

19. Ndunguru J, Taylor NJ, Yadav J, Aly H, Legg JP, Aveling T, Thompson G, Fauquet CM. Application of FTA technology for sampling, recovery and molecular characterization of viral pathogens and virus-derived transgenes from plant tissues. Virology. 2005;25:425.

20. Johnson DJ, Ostlund EN, Pedersen DD, Schmitt BJ. Detection of North American West Nile virus in animal tissue by a reverse transcription-nested polymerase chain reaction assay. Emerg Infect Dis. 2001;7:739-41.

21. Wheeler SS, Langevin SA, Brault AC, Woods L, Carroll BD, Reisen WK. Detection of persistent West Nile Virus RNA in experimentally and naturally infected Avian hosts. Am J Trop Med Hyg. 2012;87:559-64.

22. Tamura K, Stecher G, Peterson D, Filipski A, Kumar S. MEGA6: Molecular Evolutionary Genetics Analysis version 6.0. Mol Biol Evol. 2013;30:2725-9.

23. May FJ, Davis CT, Tesh RB, Barrett ADT. Phylogeography of West Nile virus: from the cradle of evolution in Africa to Eurasia, Australia, and the Americas. J Virol. 2011:85:2964-74.

24. Smithburn KC, Jacobs HR. Neutralization-tests against neurotropic viruses with sera collected in central Africa. J Immunol. 1942;44:9-23.

25. Melnick JL, Paul JR, Riordan JT, Barnett VH, Goldblum N, Zabin E. Isolation from human sera in Egypt of a virus apparently identical to West Nile virus. Proc Soc Exp Biol Med. 1951;77:661-5.

26. Lwande OW, Lutomiah J, Obanda V, Gakuya F, Mutisya J, Mulwa F, et al. Isolation of tick and mosquito-borne arboviruses from ticks sampled from livestock. 2013. p. 13.

27. Rappole JH, Derrickson SR, Hubálek Z. Migratory birds and spread of West Nile virus in the Western Hemisphere. Emerg Infect Dis. 2000;6:319-28.

28. Eidson M, Komar N, Sorhage F, Nelson R, Talbot T, Mostashari F, et al. Crow deaths as a sentinel surveillance system for West Nile virus in the northeastern United States, 1999. Emerg Infect Dis. 2001;7:615-20.

29. Work TH, Hurlbut HS, Taylor RM. Indigenous wild birds of the Nile delta as potential West Nile virus circulating reservoirs. Am J Trop Med Hyg. 1955;4:872-88.

30. Mclntosh BM, Dickinson DBMG. Ecological studies on Sindbis and West Nile viruses in South Africa. V. The response of birds to inoculation of virus. S Afr J Med Sci. 1969;34:77-82.

31. Bakonyi T, Hubálek Z, Rudolf I, Nowotny N. Novel flavivirus or new lineage of West Nile virus, Central Europe. Emerg Infect Dis. 2005;11:225-31.

32. Lanciotti RS, Ebel GD, Deubel V, Kerst AJ, Murri S, Meyer R, et al. Complete genome sequences and phylogenetic analysis of West Nile virus strains isolated from the United States, Europe, and the Middle East. Virology. 2002;298:96-105. 
33. Botha E, Markotter W, Wolfaardt M, Paweska JT, Swanepoel R, Palacios G, Nel LH, Venter M. Genetic determinants of virulence in pathogenic lineage 2 West Nile Virus Strains. Emerg Infect Dis. 2008;14:222-30.

34. Lu Z, Fu S-H, Cao L, Tang C-J, Zhang S, Li Z-X, et al. Human infection with West Nile Virus, Xinjiang, China, 2011. Emerg Infect Dis. 2014;20:1421-3.

35. Tajima F, Masatoshi N. Estimation of evolutionary distance between nucleotide sequences. Mol Biol Evol. 1984;1:269-85.

Submit your next manuscript to BioMed Central and we will help you at every step:

- We accept pre-submission inquiries

- Our selector tool helps you to find the most relevant journal

- We provide round the clock customer support

- Convenient online submission

- Thorough peer review

- Inclusion in PubMed and all major indexing services

- Maximum visibility for your research

Submit your manuscript at www.biomedcentral.com/submit
Biomed Central 